\title{
Suppression of trip effect in metastable steel by electrical current
}

\author{
V.V. Stolyarov ${ }^{1,2, \dagger}$ E.A. Klyatskina ${ }^{3}$, V.F. Terentyev ${ }^{4}$ \\ ${ }^{\dagger}$ vlstol@mail.ru \\ ${ }^{1}$ Mechanical Engineering Research Institute, RAS, 101990, Moscow, Russia \\ ${ }^{2}$ National Research Nuclear University MEPhI, 115409, Moscow, Russia \\ ${ }^{3}$ Universidad Politécnica de Valencia, 46022 Valencia, Spain \\ ${ }^{4}$ Institute of Metallurgy and Materials Science, RAS, 119991 Moscow, Russia
}

The present work deals with the problem of a possible application of current in deformation processes. A literature survey has shown an existence of publications on the electroplastic effect in single-phase materials without phase transformations and the lack of works on a study of the current impact on the deformation behavior of materials undergoing a phase transformation. Therefore, the influence of current regimes (density and impulse duration) and current mode (direct, pulse or multiple-pulse) on the deformation behavior of TRIP steel in austenite-martensite and completely martensite states is studied. Methods of mechanical tests, X-ray diffraction analysis and scanning electron microscopy observations of fracture surfaces are used. In the absence of current the steel in austenite- martensite state displays a martensitic transformation during tension that leads to an excellent combination of mechanical properties - high ultimate tensile stress and preservation of the initial ductility. It is shown that in austenite-martensite state the shape of the stress-strain tension curve and the type of flow stress jumps caused by martensitic transformation and electroplastic effect depend on the current mode. Single current pulses exert practically no influence on the mechanical properties and deformation behavior in tension. The multiple-pulse and direct current cause a considerable thermal effect, decrease in the electroplastic effect and a suppression of the TRIP effect. As a result, both the ultimate tensile stress and elongation to failure decrease. The steel in martensite state displays no TRIP effect during tension with current due to the lack of a reverse transformation, and the elongation to failure sharply decreases. According to scanning electron microscopic observations, the failure mode of samples in both states, irrespective of current, corresponds to a mechanism of ductile cleavage or shear.

Keywords: pulse current; deformation; fracture; phase transformation; tension; TRIP effect.

\section{Подавление трип эффекта в метастабильных сталях электрическим током}

\author{
Столяров В.В. ${ }^{1,2, \dagger}$, Кляцкина Е.А. ${ }^{3}$, Терентьев В.Ф. ${ }^{4}$ \\ ${ }^{1}$ Институт машиноведения РАН, 101990, Москва, Россия \\ ${ }^{2}$ Национальный исследовательский ядерный университет МИФИ, 115409, Москва, Россия \\ ${ }^{3}$ Политехнический Университет Валенсии, 46022, Валенсия, Испания \\ ${ }^{4}$ Институт металлургии и матеиаловедения РАН, 119991, Москва, Россия
}

Работа связана с проблемой возможного применения тока при деформационных процессах. Литературный анализ продемонстрировал наличие статей по электропластическому эффекту в однофазных материалах без фазовых превращений и отсутствие работ по исследованию воздействия тока на деформационное поведение в материалах, испытывающих фазовое превращение. В этой связи, исследовано влияние режимов (плотности и длительности импульса) и моды электрического тока (постоянного, импульсного, многоимпульсного) на деформационное поведение при растяжении ТРИП стали в аустенитно-мартенситном и полностью мартенситном состояниях. Использованы методы механических испытаний, рентгеноструктурного анализа и фрактографических наблюдений изломов методом сканирующей электронной микроскопии. В отсутствие тока сталь в аустенитно-мартенситном состоянии при растяжении испытывает мартенситное превращение, что приводит к отличной комбинации механических свойств - высокой прочности и сохранению исходной пластичности. Показано, что в аустенитно-мартенситном состоянии форма кривой напряжение-деформация и вид скачков напряжения течения, связанных с мартенситным превращением и электропластическим эффектом, зависят от моды тока. Одиночные импульсы тока практически не влияют на механические свойства и характер растяжения. Многоимпульсный и постоянный ток вызывают значительный тепловой эффект, снижение электропластического эффекта и подавление трип эффекта. В результате 
уменьшается и прочность, и пластичность. При растяжении с током в мартенситном состоянии сталь не испытывает трип эффекта из-за отсутствия обратного превращения, а удлинение до разрушения резко уменьшается. Характер разрушения образцов в обоих состояниях, исследованный методом электронной сканирующей микроскопии, независимо от тока, соответствует механизму вязкого отрыва или сдвига.

Ключевые слова: импульсный ток, деформация, разрушение, фазовое превращение, растяжение, трип эффект.

\section{Introduction}

Plastic deformation causes in metastable austenitic steels the martensitic transformation $\gamma$ (bcc) $\rightarrow \alpha^{\prime}$ (hcp) known as transformation induced plasticity (TRIP) effect. Many investigations have been devoted to the research of TRIP effect. The most common presentation about development in metastable austenitic steels is in the review [1]. Except a chemical composition, the grain size, strain degree and deformation temperature are the most important parameters controlling phase transformation. It is shown that the shift stresses and high pressures during the severe plastic deformation by torsion in AISI 304L steel can lead to emergence of the intermediate phase $\varepsilon$ (hcp), suggested the sequence $\gamma(\mathrm{bcc}) \rightarrow \varepsilon \rightarrow \alpha^{\prime}(\mathrm{hcp}$ ) [2]. There is a hardening due to transformation of austenite to martensite in places of possible strain location. As the world goes the strain concentrates in the austenite volumes which are next to previous location but completeness of phase transformation depends on the position of deformation temperature in relation to critical points of $M_{s}$ and $M_{d}\left(M_{s}-\right.$ start transformation temperature, $M_{d}$ - maximum deformation temperature, after that no transformation happens). In accordance with $[1,3]$ the majority of TRIP steels has distinctive feature, $M_{s}<273 \mathrm{~K}$, and $M_{d}>R T$. In [3] it has been shown that strain deformation increase and refinement structure to nano- and ultrafine grained state in metastable AISI 304L steel promotes martensite quantity increase and additional hardening, however, plasticity to fracture decreases.

Applied importance of TRIP steels consists in substantial increase not only strength, but also plasticity due to lack of necking. In this connection the choice of methods and modes of heat treatment and deformation of TRIP steels becomes especially important. The known deformation way based on electroplastic effect (EPE) was used by [4] in order to decrease the deforming stresses into a number of pure metals. Additionally, it was reported about EPE in hard-deformed and brittle materials [5, 6]. According to [7] application of current promotes some structure changes: refinement structure and increase of shape memory properties in TiNi and Ti alloys. Additionally, it was reported that EPE provokes dynamic recrystallization in magnesium alloys [8]. At the same time, it was revealed that pulse current in the TiNi alloys with martensite transformation can not only stimulate shape memory effect, but also suppresses phase transformations [9]. The study of this phenomenon is very interesting for the metastable steels with TRIP effect. However, there is not a lot paper about the influences of current on deformation behavior of TRIP steel.

The purpose of this work is research TRIP effect and EPE evaluation during static tension in metastable austenitic steel which are in the austenitic - martensitic and completely martensitic states.

\section{Experimental procedure}

Material of research was a cold rolled strip $0.30-0.35 \mathrm{~mm}$ in thickness from TRIP steel with a chemical composition of (wt.\%): $0,2 \mathrm{C}-15 \mathrm{Cr}-5 \mathrm{Ni}-3 \mathrm{Mo}-0,63 \mathrm{Si}-0,6 \mathrm{Mn}$. The phase composition of the strip surface was: 1 - austenitemartensite $(0.47 / 0.53) ; 2$ - only martensite. In the sample section, the volume fraction of martensite slightly decreases from the surface to the center.

Tension tests have been performed on the flat dog-bone shaped samples at a rate of $1 \times 10^{-3} \mathrm{c}^{-1}$ using an electric current of density $(J)$ and pulse duration $(\tau)$, are shown in Table 1 . The sample temperature was measured by means of a thermocouple with an accuracy of $\pm 5^{\circ} \mathrm{C}$.

Single current pulses have been applied to the elastic and plastic deformation area corresponding to the martensite transformation. The multiple-pulse current and direct current have been applied from the beginning of load to material fracture. The phase composition of the sample surface was defined by XRD with an accuracy of $5 \%$ by means of a diffractometer Ultima IV, "Rigaku", on the deformed part of the sample far from the location of the failure. SEM VEGA II SB TESCAN was used for fracture analysis.

\section{Results and discussion}

Tensile properties (Tabl. 1) and stress-strain curves (Figs. 1, 2) with and without current application are presented below.

We can observe from Tabl. 1 the austenite-martensite steel under tension without current application presents high strength and ductility due to TRIP effect. The application of single current pulses, even of high density, does not have significant influence on strength characteristics; however, it promotes a decrease in the elongation directly related to the quantity of impulses.

The application of multipulse and direct current leads to a decrease in UTS and YS on 15-40\%, and, in particular, an abrupt decrease in elongation. It has to be noted that the reduction of strength and plasticity presents a direct correlation with the increase of the current duration from micro - seconds up to several tenths of seconds and sample temperatures ranging from RT up to $150-200^{\circ} \mathrm{C}$. This effect is probably related to the multipulse and direct current thermal impact, heavily amplified in the neck of the deformation. From [10] it is known that an increase of the test temperature, even by $100^{\circ} \mathrm{C}$, reduces the strength of TRIP steel. The lowest strength and elongation of steel correspond to a direct current mode.

TRIP steel in martensitic state under tension with and without current application has strength characteristics considerably below than in austenite - martensite state (tabl. 1), which indicates the absence of TRIP effect. Low elongation to failure for all current modes is connected with 
Stolyarov et al. / Letters on materials 6 (4), 2016 pp. 355-359

Table 1. Mechanical properties of the TRIP steel after tension with different current modes.

\begin{tabular}{|c|c|c|c|c|c|c|}
\hline Phase state & Current regimes & Impact time, s & $T,{ }^{\circ} \mathrm{C}$ & UTS, MPa & $\mathrm{YS}, \mathrm{MPa}$ & $\delta, \%$ \\
\hline \multirow{4}{*}{$A+M$} & No current & & RT & 1680 & 1830 & 27 \\
\hline & $\begin{array}{c}\text { Single pulse } \\
J=460 \mathrm{~A} / \mathrm{mm}^{2}\end{array}$ & $30 \times 10^{-3}$ & $\mathrm{RT}$ & 1780 & 1700 & 20 \\
\hline & $\begin{array}{c}\text { Pulse current } \\
J=200 \mathrm{~A} / \mathrm{mm}^{2} \\
\tau=1 \times 10^{-3} \mathrm{~s}^{-1}\end{array}$ & 80 & 150 & 1600 & 1400 & 2.3 \\
\hline & $\begin{array}{l}\text { Direct current } \\
J=14 \mathrm{~A} / \mathrm{mm}^{2}\end{array}$ & 80 & 200 & 1350 & 1000 & 2.4 \\
\hline \multirow{4}{*}{ M } & No current & & $\mathrm{RT}$ & 1200 & 1100 & 2.5 \\
\hline & $\begin{array}{c}\text { Single pulse } \\
J=460 \mathrm{~A} / \mathrm{mm}^{2}\end{array}$ & $6 \times 10^{-3}$ & RT & 1160 & 1100 & 1.7 \\
\hline & $\begin{array}{c}\text { Pulse current } \\
J=200 \mathrm{~A} / \mathrm{mm}^{2} \\
\tau=1 \times 10^{-3} \mathrm{~s}^{-1}\end{array}$ & 50 & 150 & 1160 & 1100 & 1.2 \\
\hline & $\begin{array}{l}\text { Direct current } \\
J=14 \mathrm{~A} / \mathrm{mm}^{2}\end{array}$ & 96 & 200 & 1170 & 550 & 3.0 \\
\hline
\end{tabular}

a

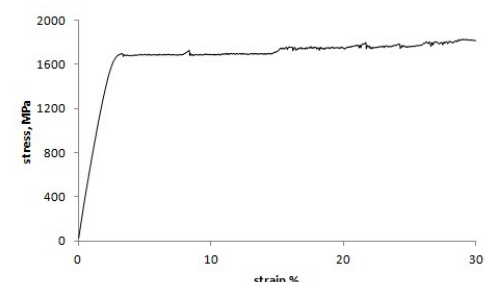

b

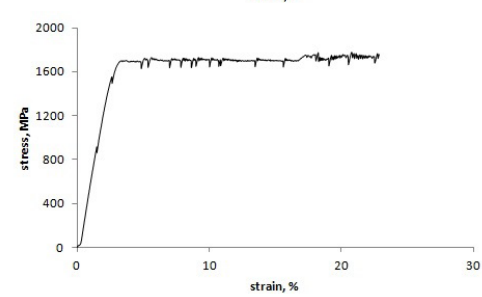

C

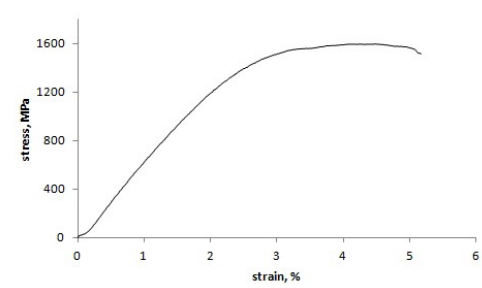

$\mathrm{d}$

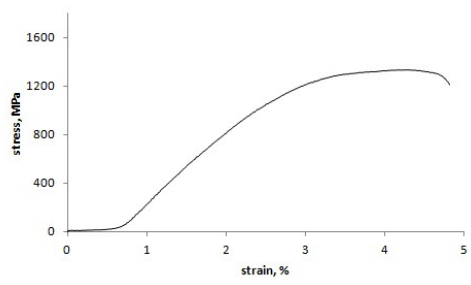

Fig. 1. Stress-strain curves of TRIP steel in austenite - martensite state: $\mathrm{a}$ - without current; $\mathrm{b}$ - single pulse current; $\mathrm{c}$-multipulse current; d - direct current.

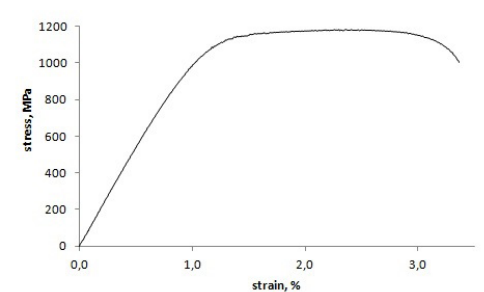

b

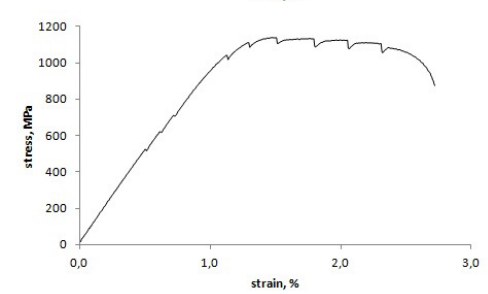

c

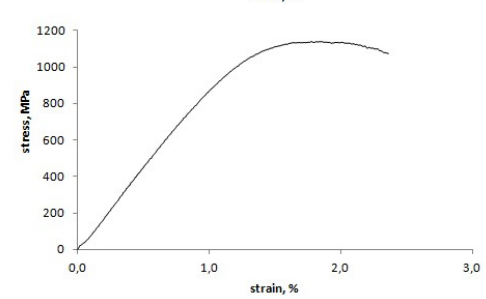

d

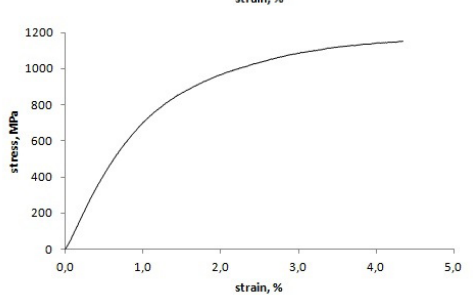

Fig. 2. Stress-strain curves of TRIP steel in martensite state: $\mathrm{a}$ - without current; $\mathrm{b}$ - single pulse current; $\mathrm{c}$-multipulse current; d - direct current. 
needle-shaped martensite grains and the limited number of sliding planes in the tetragonal lattice of martensite. It has been observed that, for both phases, the application of direct current, unlike pulse current, reduces drastically YS and prevents plasticity reduction.

Another reason for strength and plasticity decrease with the multipulse current application can be the cyclic softening/hardening effect. As a result of the fatigue, provoked by the thermal and mechanical cycling, microcracks can be developed promoting the reduction of sample plasticity.

On the tensile curve without current, in austenitemartensite state, we can observe a flattened area presenting a serrated profile corresponding to plastic flow and low strain hardening (Fig. 1a). The presence of a serrated plastic flow (Luders bands) in TRIP steel is related to the deformationinduced ??-martensite making more complex the creation of a neck due to localized hardening. Single current pulses do not have a significant impact on the general shape of stress-strain curve but lead to occurrence of stress jumps downwards of amplitude ranging from 100 to $160 \mathrm{MPa}$ at the strain hardening stage (Fig. 1b). UTS of the samples tested without current application and the ones being the subject of single current pulse application remains at the same level, however, single current pulses produce a slight reduction in elongation. It would be possible to conclude that the presence of stress jumps downwards is connected with a strong local warming up or a reverse transformation martensite to austenite. However, as the flow stress at a strain hardening stage practically does not change, the phase composition should also not change significantly. Available data for some materials reported in [11] indicates a weak thermal effect induced by the application of single current pulses, in particular less than $20-40^{\circ} \mathrm{C}$. Thus, stress jumps downwards on the tensile curves are the result of EPE. On the other hand, it is not clear to what phase EPE corresponds as the TRIP steel is in a two-phase state. It is possible to assume that EPE appears in the martensite phase (stress jumps downwards) but TRIP-effect appears in the austenite phase (stress jumps upwards). We can observe that the stress jumps also appear in the elastic area (Fig. 1b), the given fact is in contradiction to the expected dislocation mechanism of EPE discussed in [4].

Stress-strain curve changes sharply at the application of multipulse and direct current (Fig. 1c,d). The stress-strain curves get a typical shape for the stable austenite steel, with the developed stage of strain hardening and strain localization (necking). The stress jumps are not registered because of small pulse duration and large pulse frequency (Fig. 1c). Similar changes can be explained by significant thermal effect of current. The temperature measured on a surface of samples, for the current regimes raises up to $150-200^{\circ} \mathrm{C}$, and the local temperature inside of the sample can be still above and correspond to ratio $T_{d}>M_{d}\left(T_{d}-\right.$ deformation temperature). It is known that in case of the deformation temperature rises more than $300^{\circ} \mathrm{C}$, strength and ductility of TRIP steel decrease sharply. It is connected with stabilization of the austenite to martensite transformation as the transformation driving force decreases [12].

In martensite TRIP steel, the strain hardening is practically absent from the tensile curve produced without current, therefore strength and ductility are noticeably lower in comparison with TRIP steel in austenite-martensite state (Fig. 2a). The application of single current pulses does not change the general shape of the tensile curve, but leads to occurrence of stress jumps downwards with amplitude of $60 \mathrm{MPa}$ connected with EPE in martensite (Fig. 2b). As well as austenite - martensite steel, stress jumps appear not only in the flow stage but also in the elastic area that contrasts with the EPE mechanism based on the dislocation movement. The general shape of the tensile curve and the softening stage (necking) at multipulse current introduction are kept (Fig. 2c) but stress jumps are not observed, as well as austenite-martensite TRIP steel.

The application of direct current leads to the apparition of clearly remarked stage of strain hardening which is typical for austenitic state (Fig. 2d). The tensile curve shape correlates with the raised sample temperature (Tabl. 1) that is higher than the possible martensitic transformation temperature. The X-ray investigations of austenite-martensitic TRIP steel have shown that tension without current increases the martensite volume fraction from 47 up to $82 \%$. After tension with single current pulses and direct current, the martensite volume fraction decreases to 72 and $50 \%$ respectively which corresponds to reduction in TRIP effect.

The fracture surface observation of austenite-martensite samples after tension with single current pulses has revealed that there are areas of viscous separation with fine (area A, martensite) and large (area B, austenite) dimples size (Fig. 3a). Multipulse and direct current produce a change in the fracture mechanism from viscous separation to viscous shift that is observed for high-temperature deformation. In martensitic state the shear deformation mode is present even in the samples tested without current. In case of multipulse and a direct current the shear mode on a surface of destruction dominates (Fig. 3b).

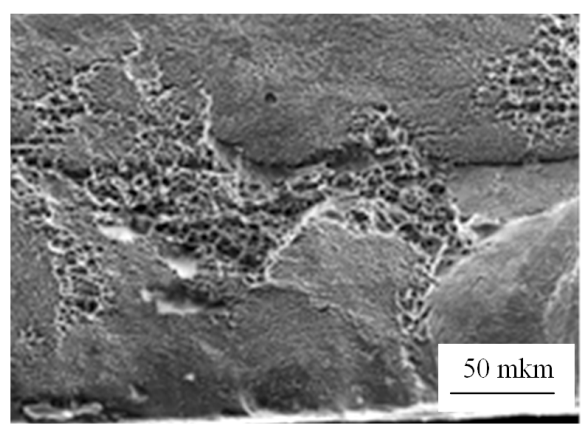

a

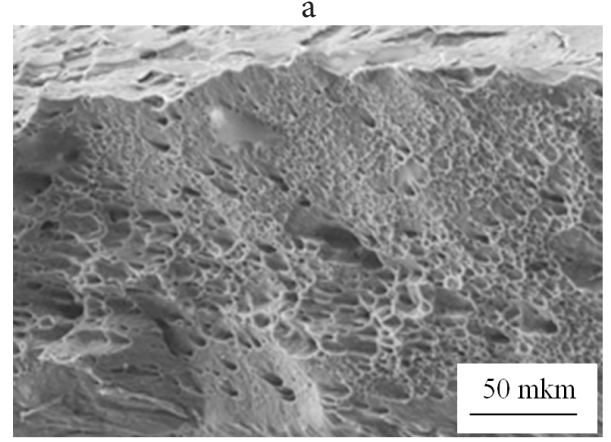

$\mathrm{b}$

Fig. 3. SEM micrographs of fracture surface in TRIP steel under single current pulse in states: $\mathrm{a}$ - austenite-martensite; $\mathrm{b}-$ martensite. 


\section{Conclusions}

The current introduction in metastable austenite-martensite steel decreases or even suppresses the TRIP effect. It depends on current mode and regimes. As a result, there is a reduction in the quantity of deformation-induced martensite, yield stress and elongation. TRIP effect depression conditioned by relation of EPE and heat effect.

Acknowledgements The authors gratefully acknowledge financial support of Russian Foundation Basically Research, the Projects no. 16-58-00152, 16-58-48001 and Russian National Foundation, №17-19-01068.

\section{References}

1. K. H. Lo, C. H., Shek, J.K. L. Lai. Mater. Sci. Eng. R. 65, 39 (2009).

2. S. Tavares, D. Gunderov, V. Stolyarov, J. Neto. Mater. Sci. Eng. A 358, 32 (2003).
3. M. Shirdel, H. Mirzadeh, M.H. Parsa. Mater. Characterization.103,150 (2015).

4. O. A. Troitskiy. JETP Letters, 10 (1), 18 (1969).

5. H. Conrad. Mater. Sci. Eng. A. 287, 276 (2000).

6. O.A. Troitskiy, Yu.V. Baranov, Yu.S. Avraamov, A.D. Shlyapin. Phisical bases and technology of modern materials treatment. V. 1, Moscow-Izhevsk, Institute of computer technologies. (2004) 590p. (in Russian).

7. V. V. Stolyarov. Letter on materials, 3, 137 (2013).

8. K. Liu., X. Dong, H. Xie, F. Peng. Mater. Sci. Eng. A. 623, 97 (2015).

9. V.V. Stolyarov. Bulletin of the RAS. Physics, 78 (3), 234 (2014).

10. M. L. Linderov, K. Zegel, A. Yu. Vinigradov, A. Vaidner, X. Birman. In: Vector of science. Tolyatti State University, 3 (25), 208 (2013).

11. U.Kh. Ugurchiev, I. A. Panteleev, O.A. Plekhov, et al. Proceedings MIKMUS. IMASH RAS, Moscow. (2009) 51. (in Russian).

12. K. I. Sugimoto, N. Usui, M. Kobayashi, S.I. Hashimoto. ISIJ International, 32, 1311 (1992). 